GOSPODARKA SUROWCAMI MINERALNYMI - MINERAL RESOURCES MANAGEMENT

\title{
An analysis of the impact of a liqudated salt mine and an municipal landfill on the quality of the Malinówka stream water in the former Barycz mining area
}

\section{Introduction}

The history of the post-mining operation in the Barycz area of the Wieliczka Salt Mine as the site of the municipal landfill for the city of Krakow dates back to 1973. The municipal landfill in the area of Barycz is an facility built and operated in the course of numerous phases (phase I and phase II - reclaimed stages, phase III - stage which is currently operating) (Fig. 1). Monitoring studies of the quality of the soil and water environment in the former Barycz mining area have been continuously conducted since 2000 (Monitoring środowiska... 2000-2014; Czajka and Kaleta 2001; Brudnik et al. 2006a; Klojzy-Karczmarczyk et al. 2012). The analysed area is characterised by the existence of several overlapping sources of surface water and groundwater contaminants. Most impurities are directly discharged into the Malinówka stream, which provides the local drainage for surface waters and partly for Quaternary aquiter. The water quality of the Malinówka stream is likely to be impacted by contaminants from various phases of the Barycz municipal waste landfill and contamination associated with the processes of changes in the rock mass in the area of the former salt mining

* D.Sc. Eng., Cracow University of Technology, Wieliczka Salt Mine, Poland; e-mail: dobyrn@pk.edu.pl

** Ph.D. Eng., *** M.Sc. Eng., Mineral and Energy Economy Research Institute, Polish Academy of Sciences, Krakow, Poland; e-mail: beatakk@min-pan.krakow.pl, jan@min-pan.krakow.pl 
borehole in the Barycz deposit. Moreover, the Malinówka basin includes a number of local watercourses and drainage ditches which are fed by contaminated rainwater and possibly domestic waste from the surrounding farms, which represents an additional source of anthropogenic pollution for the waters of the Malinówka.

The results of long-term research on the chemistry of the water in the Malinówka stream and its tributaries in the region of the potential impact of the landfill indicate periodic water contamination, mainly from chlorides and nitrogen compounds. Activities related to the construction of phase III of the landfill significantly increased the load of chlorides in the examined waters. Since the construction was completed, there has been a slow process of stabilisation of the chemical composition of the waters in the lower reaches of the Malinówka stream, and a general reduction in the level of water mineralisation has been observed (Brudnik et al. 2006a; Klojzy-Karczmarczyk et al. 2012). Monitoring studies carried out in the catchment of the Malinówka, the main stream which drains the area where the Barycz municipal waste landfill operates, indicated a change in the water chemistry already described by prior studies. The monitoring studies between 2000 and 2011 carefully analysed mandatory indices which indicate the potential impact of municipal landfills and indices considered characteristic of such facilities. The monitoring studies therefore covered concentrations of chlorides, nitrogen compounds, and contents of individual heavy metals which are mandatory and characteristic for the impact of municipal waste landfills.

It is not possible to determine the share of individual contamination sources in the general contamination of surface waters in the area of Barycz over the course of long-term environmental monitoring studies. The location of monitoring sites and the range of the studied parameters were selected based on available historical data, taking into account the local geological and hydrogeological structure and hydrological conditions in the area of potential impact of the landfill. The monitoring studies conducted on the catchment of the Malinówka stream encompass both sites on the section above the landfill (the headwaters of the stream) and a site located below the municipal landfill. The adopted sampling scheme makes it possible to compare the current level of contamination below the landfill with the local hydrogeochemical background, which the results of measurements of the chemical composition of water in the headwaters area of the Malinówka stream may be taken to represent. In subsequent periods of monitoring studies, between 2012 and 2014, this analysis included several series of quality studies of brines from pressure relief wells and groups of wells in the former Barycz mining area. By knowing the chemical composition of brines and by comparing them with the parameters characteristic of the surface water in the area associated with the impact of the landfill, conclusions can be drawn about the share of the analysed sources in the contamination of the waters of the Malinówka stream. The research conducted at this stage may be used to separate the size of the load of contaminants from different sources, i.e. those due to former mining activities as well as those due to the operation of the municipal landfill. 


\section{Historical outline of anthropogenic operations in the area of the Barycz deposit}

\subsection{History of salt deposit mining in the Barycz area}

Borehole rock salt mining at the Barycz deposit began in 1924 and continued with varying intensity until 1998. Borehole rock salt mining of the deposit first began in the area occupied today by the municipal landfill. During the entire operation of the mine, salt was extracted by leaching method. The location of production wells in the initial period was irregular. In subsequent years, numerous wells were sunk and, eventually, they were located in a dense network of irregular triangles with sides of approx. 20-70 meters. In this area of the deposit, the total original thickness of the salt formation was on average roughly $24 \mathrm{~m}$, and the depth of the top surface of the bed ranged from $146 \mathrm{~m}$ to $230 \mathrm{~m}$. In the area at present occupied by phase III of the landfill and below (phases I and II of the landfill), more than 150 wells were sunk and over 1.1 million tons of salt were mined. Most of the wells were discontinued between 1950 and 1960. Some of them were operated until the late 1980s. The operation of each well was oriented to yield maximum production, which depended on the size of the well and the size of the deposit. A side effect was the formation of local sinkholes (discontinuous deformation). Another natural outcome of the operation was the formation of an extensive subsidence trough (continuous deformation). Since the beginning of operation in the area of the Barycz deposit, 41 sinkholes were recorded, of which as many as 32 were in the "Centralne" field in the valley of the Malinówka stream. A significant number of these sinkholes (20 registered cases) have been permanently filled with brine. Some of them formed larger ponds, such as sinkholes No. 1 and No. 2, in the area where the landfill's phase III is currently located. Some sinkholes were buried in the course of works to eliminate mining damage, and some of them were used for the purpose of phase I and II of the landfill for the city of Krakow (including Mazurek 2007; d'Obyrn 2010). In this area, almost all the disused wells have been permanently eliminated. Casing and drill strings were cut off at a depth of about $2 \mathrm{~m}$ below the ground, blocked, and welded (Dokumentacja hydrogeologiczna... 1997).

\subsection{History of Barycz municipal landfill operation}

The post-mining area of borehole rock salt mining in Barycz was first used as a municipal waste landfill in 1973. Initially, the landfill was located in the northeastern part of the area, called phase I of the Barycz municipal waste landfill (Fig. 1). The landfill there was located in sinkholes resulting from the industrial processes of salt leaching. Currently, phase I of the landfill has been completely reclaimed, and the resulting biogas is tapped by a well system and used for the local needs of the installations on the site. Leachate from the drainage ditch now goes to a treatment plant via an underground pipe system. Until 2004, leachate was collected in the central collection sump, from where it was constantly pumped out and taken 
to a treatment plant. In periods of heavy rainfall, there were occasional overflows and the leachate leaked directly into the nearby Malinówka stream.

In the late 1980s, phase II of the landfill started operations (Fig. 1) and terminated in 2004. The landfill's phase II was almost completely reclaimed by 2006. In 2000, parallel with the operation of phase II, preparatory works and construction began on phase III of the landfill. Construction of the (currently operational) phase III was completed in 2004. Municipal waste has been disposed of there since the beginning of 2005. Phase III of the landfill is the most technologically developed facility (compared to the previous phases). It applies solutions which make it possible to protect the soil and water environment against migrating contaminants. During the construction of phase III it was necessary to address several serious problems, such as the elimination of ponds and sinkholes, moving the original

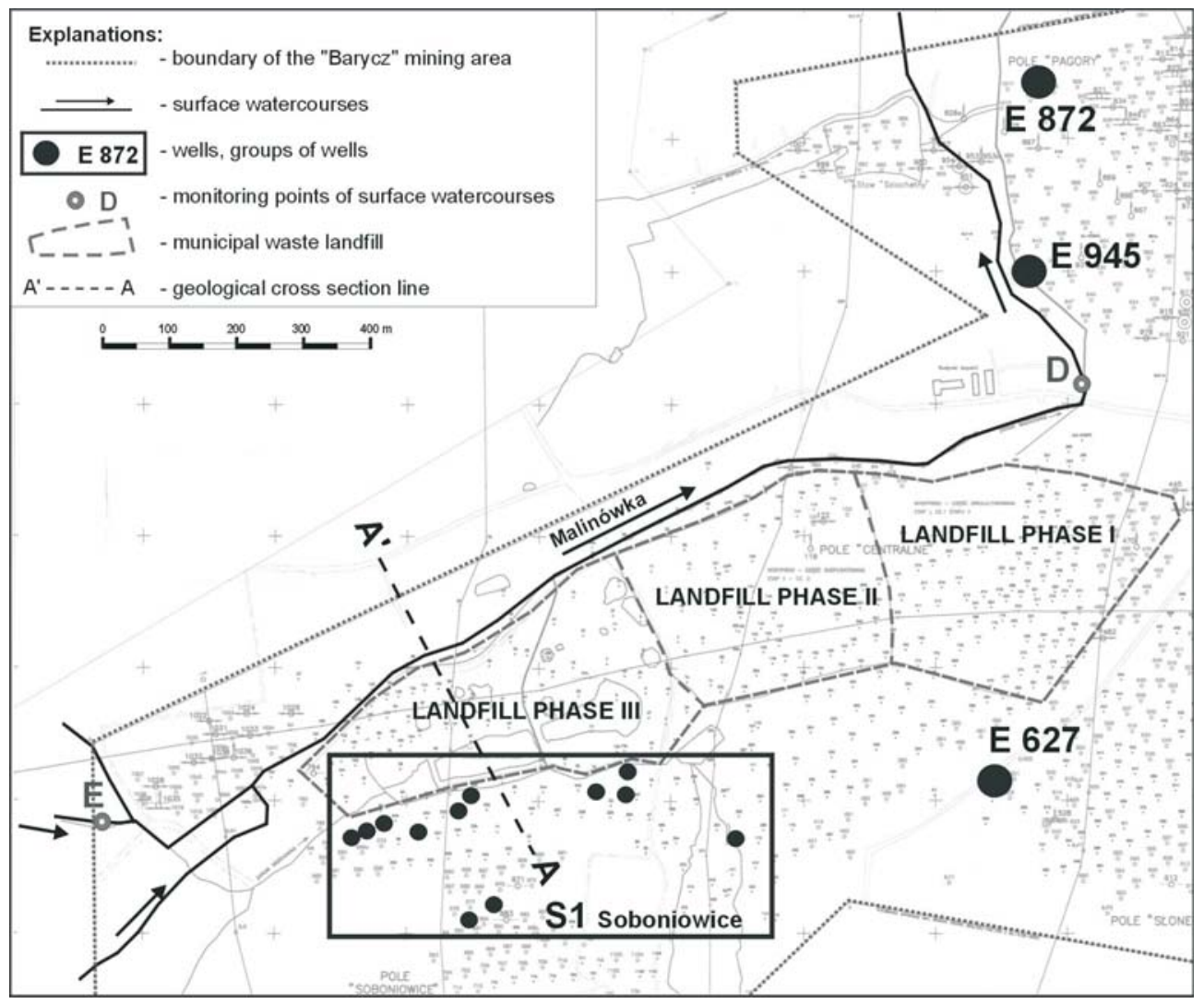

Fig. 1 Location of municipal waste landfill and selected pressure relief wells on the background of the former Barycz mining area. The geological cross-section A-A marked in the Figure was shown in previous works of the authors (Brudnik et al. 2006a; Klojzy-Karczmarczyk et al. 2012)

Rys. 1. Lokalizacja składowiska odpadów komunalnych oraz wybranych otworów odprężających na tle byłego obszaru górniczego Barycz. Zaznaczony na rysunku przekrój geologiczny A-A' przedstawiono we wcześniejszych pracach autorów (Brudnik et al. 2006a; Klojzy-Karczmarczyk et al. 2012) 
Malinówka stream bed and, especially, securing the stability of slopes on the south side of the landfill's phase III (Koncepcja programowo-przestrzenna... 1998).

\section{Description of the study area and post-mining hydrogeological conditions}

The Barycz rock salt deposit is the western extension of the Wieliczka deposit. The geological structure of the deposit is divided into two parts - the southern and the northern. A detailed description of the geological structure of the deposit, its surroundings, and its hydrogeological conditions may be found in hydrogeological records (Dokumentacja warunków... 1997-1998; Dokumentacja hydrogeologiczna... 1997) and in published works (including Garlicki and Wilk 1993; Garlicki and Szybist 1995; Garlicki et al. 1996; Brudnik et al. 2006b; Brudnik et al. 2010; d'Obyrn 2010; Postawa and d'Obyrn 2013). The municipal waste landfill in Barycz is located entirely above the former mining area of the Barycz deposit (Fig. 1). The area of the municipal landfill is located generally over its southern part. In this area, strongly tectonically disturbed flysch formations in the form of marl claystone, siltstone, and Cretaceous sandstone are to be found under Quaternary sediments of about $5-10 \mathrm{~m}$. The thickness of the flysch formations in this region is variable and ranges from $220 \mathrm{~m}$ in the southern part of the area to approx. $150 \mathrm{~m}$ in the northern part. Flysch formations there are thrust on the Miocene salt-bearing formation. The thickness of the salt formation under the flysch varies, ranging from $45 \mathrm{~m}$ in the southern part to about $80 \mathrm{~m}$ in the northern part of the area. The salt series takes the form of rock salt deposits veined with claystone, siltstone and sandstone, anhydrite, and gypsum. The total thickness of the rock salt changes from 10 to $70 \mathrm{~m}$. The Skawina beds in the form of mudstone and sandstone are located under the salt series.

Salt borehole mining resulted in rock mass changes which greatly disturbed the original hydrogeological conditions. The impact of the mining activities seriously disturbed and changed the original isolation of the aquifers. As a result of changes in the rock mass, new hydraulic contacts appeared which could have also altered the direction and flow of groundwater in the vicinity of a landfill. Groundwater in the area of the Barycz salt deposits and their vicinity occurs in all stratigraphic divisions. The hydrogeological conditions of evaporites found directly on the Skawina beds are varied. North of the boundaries of the mining area, Bogucice sands occur in evaporite overburden, the youngest Miocene sediments. They are fed directly on the outcrops and by infiltration of Quaternary water into the rock mass, especially where it is rich in groundwater (terrace of the Vistula river, the Malinówka and Serafa stream bed). It may also be fed from Chodenice and Skawina beds at sites where they come into contact. The quality of groundwater in the Bogucice sands may have a direct impact on contamination of the Malinówka stream in the sections of infiltrating nature. They may also be fed by the Chodenice and Skawina beds where they come into contact. The quality of groundwater in the Bogucice sands may be directly impacted by 
contamination of the Malinówka stream. Quaternary sediments occur virtually throughout the Barycz mining deposits. The thickness of aquifers within the Quaternary is low, ranging from 0.5 to approx. $10 \mathrm{~m}$.

Hydrographically, the area of the Barycz salt deposits is located in the basin of the Vistula River within the second order of the stream Serafa. The Malinówka stream is a marginal tributary of the Serafa; it flows through the former Barycz mining area and it is a third order stream. The Malinówka headwaters area is located in the region of Soboniowice. The Malinówka stream is fed from the southern slope of the valley with two continuously flowing watercourses. In the central part of the landfill area, the Malinówka stream changes direction to the north, emptying into a closed channel running east along the northern boundary of the Barycz landfill. From Krzemieniecka Street, the Malinówka stream flows again in a natural riverbed, passing outside the former Barycz mining area over outcrops of Bogucice sands (Figure 1). The Malinówka stream in its upper reaches drains groundwater in the valley and on its slopes, while in the lower reaches, outside the mining area, it may feed other watercourses. The Malinówka stream's hydrological regime is closely related to precipitation and temperature (Wardas et al. 2005).

The area of mining operations in the Barycz salt deposit was conventionally divided into four mining plots - the "Centralne" field, the "Słoneczne" field, and the "Soboniowice" and "Pagory" fields. These distinctions were mainly determined by morphology, the hydrography of the area, and technical considerations. The "Centralne" field was operated continuously between 1925 and 1965 and, additionally, in the 1908s and early 1990s. This field, of an area of 53.7 hectares, is the largest mining region in the area of the Barycz mine. From the south and southeast it borders with the "Soboniowice" and "Słoneczne" fields. It covers the morphologically lowest area through which flows the stream Malinówka (Fig. 1). The "Słoneczne" field was operated from 1961-1969 and 1995-1996, and covers an area of 16.4 hectares. Morphologically, the "Słoneczne" field covers an area located on the northern and north-eastern slope of Grabówek hill. A number of production wells, of which the vast majority have now been eliminated, were located on the fields. Upon completion of operations, measures were implemented which included the elimination of production and research wells (with the exception of the pressure relief or piezometric wells) and elimination of caverns (cavities). Measures have also been taken to remove or develop the technical infrastructure directly related to the mining of the deposit (reservoirs, pipelines, etc.), and to remove machinery and equipment. The post-mining areas have been reclaimed; safeguards against contamination were fitted in the area along with a system to monitor the processes occurring in the rock mass and the environment.

As a means of preventing the possibility of contamination of the area with brine from the caverns, which underwent spontaneous tightening, a number of wells were left behind which were to act as a pressure relief mechanism and for observation purposes. The observations are conducted in 7 pressure relief wells in the "Soboniowice" field, 3 wells in the "Stoneczne" field and in 2 wells in the "Pagory" field. Brine from the pressure relief caverns, obtained in the process of destressing converging caverns, is collected in reservoirs at the opening, from 
where it is then pumped and transported by truck cisterns for the water storage reservoirs for the process of utilization of saline waters in the Wieliczka Salt Mine. According to the plan for the years 2013-2018, 23 wells used for pressure relief and for observation purposes have been left behind in the borehole of the Barycz mine. Wells for the purpose of pressure relief for the rock mass have been listed in Figure 1.

The individual mining fields tend to display different geological structures of sediments forming overburden above the bed of rock salt and different hydrogeological conditions. In the "Soboniowice" and "Słoneczne" fields, the overburden is rich in flysch. In terms of hydrogeology, the flysch formations in the Barycz mine have not been identified. In the region of the southern boundary of the Barycz rock salt bed there are garden wells which are likely to draw water from the flysch formations. Water in the flysch formations occurs mainly in fissured sandstones or is associated with the zones of tectonic fissures. Shale or clay formations are not water-bearing. In the area of the Barycz mine, the water-bearing flysch where water circulation may occur is probably located at a depth of about $60 \mathrm{~m}$; the deeper parts may be practically watertight except for the fault zones and fissures in the rock. The layer is fed by indirect infiltration of precipitation through the Quaternary sediments.

In the "Pagory" field, in the deposit overburden, there are Chodenice beds in allochtonic position. The extent of water concentration of these and other layers is very poorly known. Data from the drilling of hydrogeological boreholes indicate the presence of water in sand-sandstone, dolomite, and marine tuff, which are characterised by a large and dense network of fissuring. Zones of intense fissuring within clay-slate and mudstone - in particular, sandy ones - may also be water-bearing. The permeability coefficient of the examined layers is likely to be very diverse. It is assumed that in general within the whole complex of permeable rock it is less than $10^{-6} \mathrm{~m} / \mathrm{s}$. The waters of these layers may be considered porous-creviced with a confined, subartesian groundwater table.

The flysch formations in the "Soboniowice" and "Słoneczne" fields and the Chodenice beds in the "Pagory" field are covered by Quaternary sediments mainly of loam, fine and medium sands, and silted sands. The groundwater table is generally free, but in places it may be confined. On the basis of the interpretation of the geological profiles of production and research wells in areas where pressure relief systems were built for the post-mining fields, the formations are generally poorly water-bearing capacity. Distribution of Quaternary aquifer hydroizohypses generally indicates groundwater flow from south to north. Local changes in the direction of water flow are associated with the relief of the terrain and the presence of surface watercourses which drain their catchment area. Directions of groundwater flow in Quaternary aquiter are directed towards the natural axis of the valley floor of the Malinówka stream. The extent of water concentration in the Quaternary aquifer of the "Soboniowice" field and water chemistry in these formations may be affected by the presence of the phase III Barycz municipal waste landfill. The southern boundary of the landfill is located directly on the pressure relief system of wells in the "Soboniowice" field. The complicated tectonic form, wide occurrence of Quaternary sediments, and contacts 
with Bogucice sandstone provide favourable conditions for the hydraulic connections between aguifers in the deposit overburden.

\section{Basic scope of research}

The paper presents the results for water sampled from pressure relief wells to determine the concentration of selected components. The analysed wells are located near the Barycz municipal waste landfill (Figure 1):

- E-872 and E-945 wells are located in the western part of the "Pagory" field on the right slope of the Malinówka stream below phase I of the landfill,

- E-627 well which forms part of a system of three wells, located in the south-western part of the "Słoneczne" field at phase I of the landfill,

- a group of wells in the northern part of the "Soboniowice" field (S1 "Soboniowice" reservoir) is located on the southern slope of the old bed of the Malinówka stream directly on the southern boundary of phase III of the municipal landfill.

Pressure relief wells in the "Soboniowice" field and "Słoneczne" field operate in collective systems. In these systems, the wells in each field are connected to a collective pipeline which discharges the extruded brine into a field reservoir. The wells of the "Pagory" field operate on an individual basis and the extruded brine is discharged directly into the field reservoir at the well. Brines collected from the pressure relief wells or collecting system were measured for electrical conductivity, and concentrations of nitrogen, phosphorus, and total mercury compounds were determined. The wells were sampled 4 times from 2012-2014 under various hydrological conditions (Table 2).

The second element of this research is the results of monitoring the surface water quality of the Malinówka stream in the vicinity of the municipal landfill, also between 2012 and 2014. Water samples for physico-chemical studies were collected several times a year (5-6 samples per quarter), and the results presented in this paper are listed, averaged values for each quarter of each year. Water samples were collected at fixed monitoring sites (location in Figure 1), the same ones from which the results were the subject of previous publications by the authors (Brudnik et al 2006a; Klojzy-Karczmarczyk et al. 2012):

- point E-above III, the newest phase of the landfill at the inflow of waters which feed the Malinówka stream,

- point D - below the closed phases I and II of the landfill.

Monitoring studies of the Malinówka water quality in the vicinity of the landfill, located in the Barycz mining area, have been performed since 2000 by Wieliczka Salt Mine and MEERI PAS (Monitoring środowiska... 2000-2014). Long-term monitoring has been conducted to check the status of the Malinówka stream waters in the former Barycz mining area. The adopted sampling system allows for a comparison of the current contamination levels below the landfill with the results of measurements of the composition of the water courses in the area of the headwaters of the Malinówka stream. 
Between 2000 and 2014, rigorous inspections were conducted of indices adopted as mandatory in monitoring studies of the impact of municipal landfills and indices considered characteristic of such facilities in the earlier works of the authors and in other studies (including James 1977; Żygadło 2002; Klojzy-Karczmarczyk et al. 2003; Brudnik et al. 2006a; Mikołajczak 2006; Klojzy-Karczmarczyk and Mazurek 2009; Witkowski 2009; Klojzy-Karczmarczyk and Mazurek, 2010; Rosik-Dulewska 2011; Szymański and Nowak 2012; Lebiocka 2013). The monitoring studies therefore included chloride concentration, nitrogen and phosphorus compounds, and the content of individual heavy metals adopted as mandatory $(\mathrm{Cu}, \mathrm{Zn}, \mathrm{Pb}, \mathrm{Cd}, \mathrm{Cr}, \mathrm{Hg})$ which are characteristic of the impact of municipal waste landfills. Physical and chemical analyses of water samples were conducted in the laboratory of the Mineral and Energy Economy Research Institute of the Polish Academy of Sciences. Analysis of the quality of surface waters and brines may be an important element in the process of identifying contamination sources caused by discontinued mining operations and operation of the municipal landfill. The presumed groundwater flow with the potential mixing zone of rainwater, shallow groundwater, and landfill leachate are shown in Figure 2.

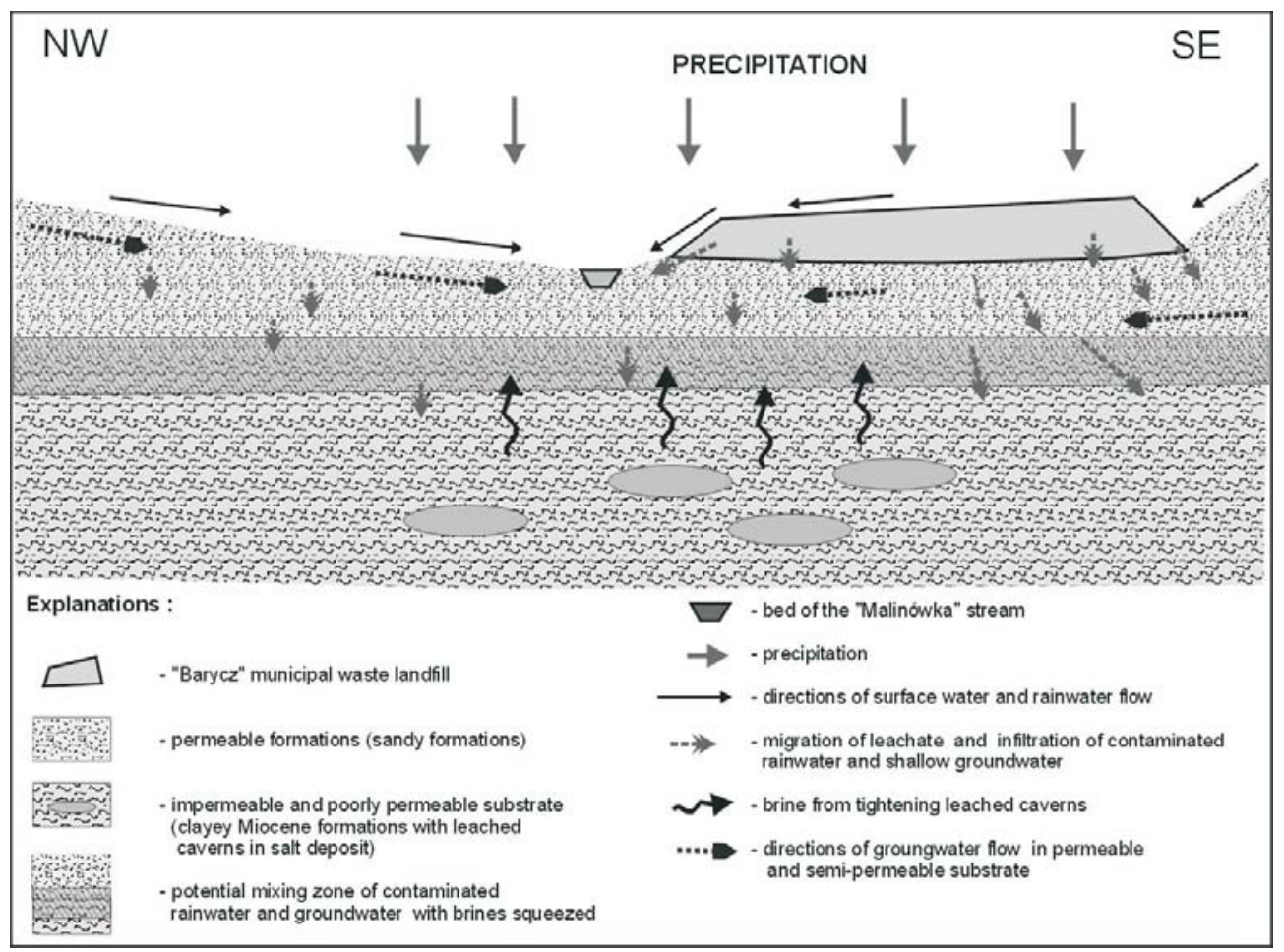

Fig. 2. Simplified scheme of water flow in the vicinity of municipal landfill in the former Barycz mining area

Rys. 2. Uproszczony schemat przepływu wód w otoczeniu składowiska odpadów komunalnych na byłym obszarze górniczym Barycz 
Laboratory measurements of the individual components and parameters of brines and surface waters of the Malinówka stream were conducted by atomic absorption and emission spectrometry using a Perkin-Elmer AES-ICP spectrometer and HACH UV-Vis spectrophotometer. Mercury content was determined by a dedicated atomic absorption spectrometer Altec AMA-254.

\section{The research results and their interpretation}

This section presents averaged quarterly results of the Malinówka stream water quality between 2012 and 2014. Measurements include indices typical for municipal waste landfills showing potential contamination of groundwater, i.e. the concentration of chlorides and nitrogen and phosphorus compounds (in the form of nitrates and phosphates). For comparison, each of the graphs (Fig. 3, 4, 5) shows the change in the size of the index at the site above the landfill (point E) and at the monitoring site below the landfill (point D), with respect to the electrical conductivity which reflects water mineralisation. For every quarter in the examined years, the arithmetic mean of all the measurements was calculated (sampling was carried out generally twice a month). The concentrations of chlorides, nitrates, and phosphates in the Malinówka stream water sampled between 2012 and 2014 at a site below

Table 1. Listed components measured in waters of the Malinówka stream in the vicinity of Barycz municipal landfill

Tabela 1. Zestawienie oznaczonych składników w wodach potoku Malinówka w otoczeniu składowiska odpadów komunalnych Barycz

\begin{tabular}{|c|c|c|c|c|}
\hline \multirow{3}{*}{ Measured component } & \multicolumn{2}{|c|}{ Point E above the landfill } & \multicolumn{2}{|c|}{ Point D below the landfill } \\
\hline & \multicolumn{4}{|c|}{ Monitoring studies - averaged valued between Jan. 2012 and June 2014} \\
\hline & range & averaged value & range & averaged value \\
\hline Electrical conductivity $[\mathrm{mS} / \mathrm{cm}]$ & $0.37-0.46$ & 0.40 & $0.66-1.09$ & 0.81 \\
\hline Chlorides $\left[\mathrm{mg} / \mathrm{dm}^{3}\right]$ & $44.9-50.8$ & 48.4 & $125.6-260.7$ & 192.0 \\
\hline Phosphates $\left[\mathrm{mg} / \mathrm{dm}^{3}\right]$ & $0.02-0.11$ & 0.04 & $0.18-0.49$ & 0.35 \\
\hline Nitrates $\left[\mathrm{mg} / \mathrm{dm}^{3}\right]$ & $1.55-2.03$ & 1.78 & $3.15-4.65$ & 3.90 \\
\hline Mercury $\left[\mathrm{mg} / \mathrm{dm}^{3}\right]$ & $0.00051-0.00078$ & 0.00063 & $0.00079-0.00118$ & 0.00096 \\
\hline Copper $\left[\mathrm{mg} / \mathrm{dm}^{3}\right]$ & $<0.010$ & $<0.010$ & $<0.010-0.020$ & 0.013 \\
\hline Zinc $\left[\mathrm{mg} / \mathrm{dm}^{3}\right]$ & $<0.010-0.013$ & $<0.010^{*}$ & $0.014-0.064$ & 0.025 \\
\hline Chromium $\left[\mathrm{mg} / \mathrm{dm}^{3}\right]$ & $<0.010$ & $<0.010$ & $<0.010-0.015$ & $<0.010^{*}$ \\
\hline Lead $\left[\mathrm{mg} / \mathrm{dm}^{3}\right]$ & $<0.010$ & $<0.010$ & $<0.010$ & $<0.010$ \\
\hline Cadmium $\left[\mathrm{mg} / \mathrm{dm}^{3}\right]$ & $<0.010$ & $<0.010$ & $<0.010$ & $<0.010$ \\
\hline
\end{tabular}

* Results of determinations of zinc and chromium above the limit of quantification have been occasionally observed in individual samples from the general population $\left(>0.010 \mathrm{mg} / \mathrm{dm}^{3}\right)$ 
the landfill are, on average, several times higher than in the headwater regions which are regarded as the benchmark (Table 1). The chloride content in the water above the landfill is on average about $50 \mathrm{mg} / \mathrm{dm}^{3}$, while below the landfill it increases 4-fold, often exceeding $200 \mathrm{mg} / \mathrm{dm}^{3}$ (Fig. 3). The nitrate content increases two-fold from an average value of $2 \mathrm{mg} / \mathrm{dm}^{3}$ to $4 \mathrm{mg} / \mathrm{dm}^{3}$. Phosphate content is much lower. Above the landfill the average content is low at $0.05 \mathrm{mg} / \mathrm{dm}^{3}$, and below the landfill it increases slightly (Table 1, Fig. 4).

In recent years, following a period of increased chloride emissions to surface waters observed from 2002-2004 during the construction works of landfill's phase III (Brudnik et al. 2006a), a slow stabilisation of the majority of studied indicators of water contamination has been observed. However, an increase in mineralisation and macronutrients characteristic of leachate from the municipal waste landfill in the waters below the landfill is clearly visible. Due to the geological and hydrogeological conditions of the area, the visible increase in the chloride content in the waters of the Malinówka stream may be related to the impact of the remains of the discontinued borehole salt mining and of the landfill. In contrast, an increase in the levels of nitrates and phosphates may be a result of the likely impact of the landfill or local watercourses and drainage ditches fed by contaminated rainwater, and possibly domestic waste from the nearby farms.

In the course of the monitoring study of the Malinówka stream water in the years 2012-2014, a study was also conducted of the concentration of heavy metals like indices, which are considered mandatory in accordance with regulations - the Regulation of the Minister of Environment of 30 April 2013 on landfills (OJ 2013 item 523). Generally, there is no significant increase in heavy metal content at the site below the landfill, and their values both at point $\mathrm{E}$ as well as point $\mathrm{D}$ are low, often below the limit of quantification (Table 1). In the waters of the Malinówka stream below the landfill, only a slight increase in the content of copper and zinc is observed and, in individual cases, of chromium, which was also listed on a quarterly basis in Figure 5. An increase in the content of certain metals in the waters may further suggest a negative impact of the landfill, especially phase I.

The presence of mercury in the waters of the Malinówka stream (Table 1, Fig. 5) is an interesting issue. Although its content is low, almost at the lower limit of quantification according to the method applied at the site above the landfill, below the landfill its content increased nearly 2 -fold. Mercury content varies from the average value of $0.00063 \mathrm{~m} / \mathrm{dm}^{3}$ to $0.00096 \mathrm{mg} / \mathrm{dm}^{3}$. The limit of quantification of mercury in aqueous solutions using an Altec AMA-254 atomic absorption spectrometer is $0.0004-0.0005 \mathrm{mg} / \mathrm{dm}^{3}$ (depending on the calculation method). Mercury is a required component in monitoring for the impact of municipal solid waste landfills. The presence of mercury in the leachate from the municipal landfill of several to about a dozen $\mu \mathrm{g} / \mathrm{dm}^{3}$ was confirmed in other works (include James 1977; Klojzy-Karczmarczyk et al. 2003). Thus, the observed slight increase in mercury content may be the result of the impact of the municipal waste landfill. It should be emphasised that mercury content measured in the waters of the Malinówka stream is at the level reported in previous studies for surface water in Poland (Kabata-Pendias and Pendias 1999). With respect to the Regulation of the Minister of Environment of 22 October 2014 


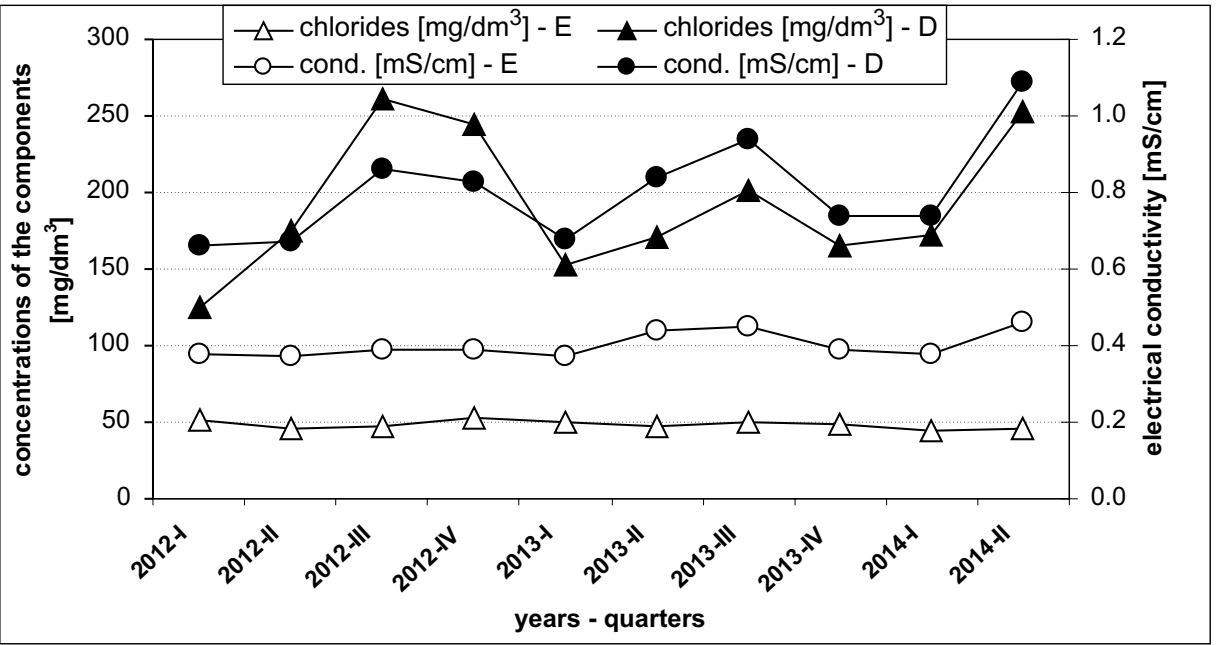

Fig. 3. Averaged chloride content in the successive quarters of 2012-2014 in the waters of the Malinówka stream at sampling points located in the immediate vicinity of Barycz municipal waste landfill

Rys. 3. Uśrednione zawartości chlorków w poszczególnych kwartałach lat 2012-2014 w wodach potoku Malinówka w punktach pomiarowych położonych w bezpośrednim otoczeniu składowiska odpadów komunalnych Barycz

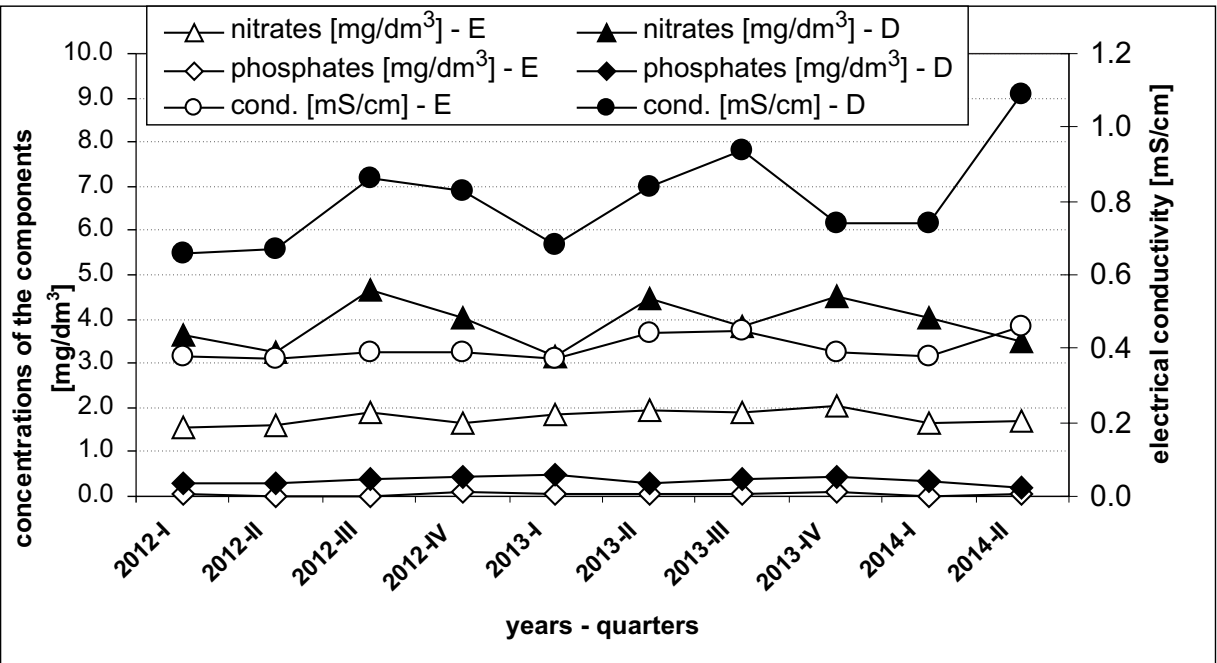

Fig. 4. Averaged nitrate and phosphate content in the successive quarters of 2012-2014 in the waters of the Malinówka stream at sampling points located in the immediate vicinity of Barycz municipal waste landfill

Rys. 4. Uśrednione zawartości azotanów i fosforanów w poszczególnych kwartałach lat 2012-2014 w wodach potoku Malinówka w punktach pomiarowych położonych w bezpośrednim otoczeniu składowiska odpadów komunalnych Barycz 


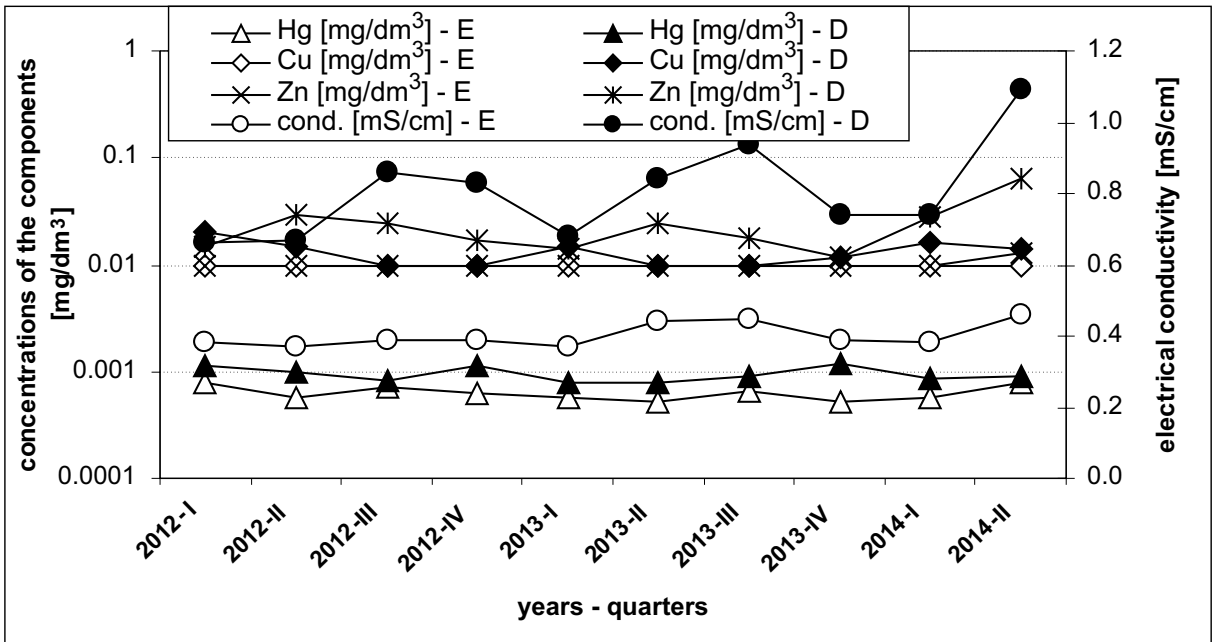

Fig. 5. Averaged mercury, copper, and zinc content in the successive quarters of 2012-2014 in the waters of the Malinówka stream at sampling points located in the immediate vicinity of Barycz municipal waste landfill

Rys. 5. Uśrednione zawartości rtęci, miedzi i cynku w poszczególnych kwartałach lat 2012-2014 w wodach potoku Malinówka w punktach pomiarowych położonych w bezpośrednim otoczeniu składowiska odpadów komunalnych Barycz

on the classification of the status of surface waters and environmental quality standards for priority substances (OJ 2014 item 1482), mercury content in the waters of the Malinówka stream exceeds by several times the environmental quality standards for mercury, as a priority substance. The maximum allowable concentration of mercury and its compounds in surface waters is $0.00007 \mathrm{mg} / \mathrm{dm}^{3}$.

In the course of the study, pressure relief wells (with process of destressing converging caverns) in the area of the mining operations of the Barycz salt deposit were also sampled 4 times between 2012 and 2014 (Table 2). The sampled brines displayed very high mineralisation. Mineralisation of brines is mainly related to the presence of chlorides. Their content in saline infiltration waters flowing near the Wieliczka salt deposit ranges from several dozen to nearly $200,000 \mathrm{mg} / \mathrm{dm}^{3}$ (Winid 2013). Electrical conductivity of the sampled brines reflects their mineralisation and displays significant differentiation from several to more than $200 \mathrm{mS} / \mathrm{cm}$ (Table 2). This parameter's variability was also demonstrated in the work of B. Winid (2013). On the basis of field identification of local hydrological conditions, it may be assumed that such a large variation of mineralisation may be caused by the mixing of saline waters and Quaternary water and rainwater collecting locally and feeding the pressure relief systems. In addition to the impact of the municipal waste landfill, the increase in the chloride content in the waters of the Malinówka stream may therefore also be the result of the parallel impact of the discontinued borehole rock salt mining (mainly pressure relief wells and deformation of rock mass). 
In addition, samples of brines were analysed for parameters which are elevated in surface waters at the site below the landfill (point D). The values of these parameters in the brine are similar to the ones obtained for the surface water of the Malinówka steam. This observation allows for the assumption that the presence of nitrate and phosphate in surface waters and brines may be due to the impact of a common source of contamination - the municipal waste landfill or, in addition, local contamination from nearby farms.

In the analysed brines, the mercury content was also measured and it was found to be at a level slightly higher than for surface water courses (Table 2). The mercury concentration in the brine ranged from 0.001 to $0.002 \mathrm{mg} / \mathrm{dm}^{3}$. The presence of mercury in the brine may suggest a two-way flow of solutions in the area resulting from specific geological conditions. This may constitute the contamination of brines by local sources of contamination, or mercury may be a component of brines and is a potential threat to the environment as a result

Table 2. Listed components measured in brine from pressure relief wells in the area of mining operations at the Barycz salt deposit

Tabela 2. Zestawienie oznaczonych składników w solankach z otworów odprężających w obszarze działalności górniczej na złożu soli Barycz

\begin{tabular}{|c|c|c|c|c|c|}
\hline \multirow[b]{2}{*}{$\begin{array}{l}\text { Measured } \\
\text { component }\end{array}$} & \multirow[b]{2}{*}{ Sampling time } & \multicolumn{4}{|c|}{ Brine sampling site } \\
\hline & & $\begin{array}{c}\text { E872 } \\
\text { ("Pagory” } \\
\text { field well) }\end{array}$ & $\begin{array}{c}\text { E945 } \\
\text { (“Pagory” } \\
\text { field well) }\end{array}$ & $\begin{array}{l}\text { E627 (collective } \\
\text { system in the } \\
\text { "Słoneczne" } \\
\text { field) }\end{array}$ & $\begin{array}{l}\text { S1 (collective } \\
\text { system in the } \\
\text { "Soboniowice" } \\
\text { field) }\end{array}$ \\
\hline \multirow{4}{*}{$\begin{array}{c}\text { Electrical } \\
\text { conductivity } \\
{[\mathrm{mS} / \mathrm{cm}]}\end{array}$} & April 2012 & 49.80 & 5.55 & $>199.99$ & 6.80 \\
\hline & November 2012 & 45.6 & 8.34 & $>199.99$ & 5.1 \\
\hline & February 2014 & 33.7 & 10.12 & $>199.99$ & $>199.99$ \\
\hline & April 2014 & 51.9 & 16.2 & $>199.99$ & $>199.99$ \\
\hline \multirow{4}{*}{$\begin{array}{c}\text { Phosphates } \\
{\left[\mathrm{mg} / \mathrm{dm}^{3}\right]}\end{array}$} & April 2012 & 0.28 & 0.17 & $<0.1$ & 0.21 \\
\hline & November 2012 & 0.18 & 0.14 & 0.12 & 0.22 \\
\hline & February 2014 & 0.19 & 0.46 & 0.09 & 0.35 \\
\hline & April 2014 & 0.24 & 0.73 & 0.14 & 0.47 \\
\hline \multirow{4}{*}{$\begin{array}{l}\text { Nitrates } \\
{\left[\mathrm{mg} / \mathrm{dm}^{3}\right]}\end{array}$} & April 2012 & 5.6 & 6.3 & 3.3 & 18.9 \\
\hline & November 2012 & 7.1 & 4.2 & 2.7 & 8.9 \\
\hline & February 2014 & 7.2 & 9.2 & 5.4 & 11.7 \\
\hline & April 2014 & 10.6 & 11.9 & 4.7 & 8.6 \\
\hline \multirow{4}{*}{$\begin{array}{l}\text { Mercury } \\
{\left[\mathrm{mg} / \mathrm{dm}^{3}\right]}\end{array}$} & April 2012 & n.m. & n.m. & n.m. & n.m. \\
\hline & November 2012 & n.m. & n.m. & n.m. & n.m. \\
\hline & February 2014 & 0.00185 & 0.00198 & 0.00134 & 0.00147 \\
\hline & April 2014 & 0.00167 & 0.00192 & 0.00187 & 0.00109 \\
\hline
\end{tabular}


of pumping brines out of the rock mass. It is not possible to determine the direction of flow of contaminants and the share in individual emission sources based on the study.

\section{Summary and Conclusions}

The Malinówka stream, which drains local surface waters and partly groundwaters, is the direct discharge site of most impurities. The monitoring study and the interpretation of the results in the described area have been hindered due to the overlapping of many factors (natural and anthropogenic) influencing the chemistry of surface water in streams within the potential impact zone of the landfill, and at the same time located within specific hydrogeological conditions. The paper describes the current findings and indicates the values close to those obtained in the course of research before 2012, but definitely after the activities related to the construction of the phase III of the landfill. The quality of the Malinówka stream water is probably most impacted by contamination from the Barycz municipal landfill and contamination associated with the processes of changes in the rock mass in the area of the former salt mining borehole in the Barycz deposit. The surrounding farms may also provide an additional source of anthropogenic contamination.

Analysis of the quality of water in the Malinówka stream and of brines and their coexistence may be an important element in the process of identifying contamination sources from former mining operations and the operation of the municipal landfill. The presumed directions of infiltration water and groundwater flow indicate a potential mixing zone of rainwater, shallow groundwater, and landfill leachate. Due to the geological and hydrogeological conditions of the area, a visible increase in the chloride content in the waters of the Malinówka stream may be related both to the impact of the landfill as well as to the impact of the discontinued operation of the borehole rock salt mining. In contrast, an increase in the levels of nitrates and phosphates is most likely the result of the impact of the landfill, or local watercourses and drainage ditches fed by contaminated rainwater and possibly domestic waste from nearby farms. Additionally, the increase in the levels of certain metals in the waters may suggest a negative impact of the part of landfill.

Analysis of the chemical composition of brines, and a comparison with the parameters characteristic of the surface water in the area impacted by the landfill, confirms the interaction of individual facilities in this area. The existing hydrogeological system is complex, in particular the processes of mutual impact of the former salt mining and the section of the landfill which was built and operated in three phases. The results of the existing research make it possible to confirm the character of the contamination sources, but not to make a more accurate determination of the contaminants' impact on the size of the cumulative contaminant load in the Malinówka stream below the mining area, and thus below the Barycz landfill, in particular in the area which contains structures and which was operated in the phase I. Verification and extension of research in the analysed area are recommended to achieve this aim. 
This study was partially conducted within the framework of the statutory operations of the Mineral and Energy Economy Research Institute of the Polish Academy of Sciences

\section{REFERENCES}

Brudnik et al. 2006a - Brudnik, K., Klojzy-Karczmarczyk, B. and Mazurek, J. 2006. Środowisko gruntowo-wodne w rejonie składowiska odpadów komunalnych na obszarze historycznej eksploatacji złoża soli kamiennej „Barycz”; (The soil-water environment in the area of the municipal waste dump in Barycz - the place of a historic salt deposit exploitation). Gospodarka Surowcami Mineralnymi - Mineral Resources Management Vol. 22, special issue 3, pages 31-42 (in Polish).

Brudnik et al. 2006b - Brudnik, K., Przybyło, J. and Winid, B. 2006. Zawodnienie złoża soli Wieliczka na podstawie stanu wycieków kopalnianych. Wiertnictwo Nafta Gaz Tom 23/1. AGH Uczelniane Wydawnictwa Naukowo-Dydaktyczne, Kraków; pages 101-109 (in Polish).

Brudnik et al. 2010 - Brudnik, K., Czop, M., Motyka, J., d’Obyrn, K., Rogoż, M. and Witczak, S. 2010. The complex hydrogeology of the unique Wieliczka salt mine. Przeglad Geologiczny Vol. 58, No 9/1, pages 787-796.

Czajka, K. and Kaleta, R. 2001. Wybrane zagadnienia monitoringu środowiska Obszaru Górniczego „Barycz” i składowiska odpadów komunalnych Barycz w Krakowie. Materiały sympozjum nt. „Zagrożeń naturalnych w górnictwie"; 29 maja-1 czerwiec 2001, Wieliczka (in Polish).

Dokumentacja hydrogeologiczna...1997 - Dokumentacja hydrogeologiczna złoża soli „Barycz” dla potrzeb projektu likwidacji kopalni, stan na grudzień 1996 r., 1997- OBR GSCh 'Chemkop”, Kraków (unpublished work, the Archive of Wieliczka Salt Mine) (in Polish).

Dokumentacja warunków... 1997-1998 - Dokumentacja warunków hydrogeologicznych dla koncepcji programowo-przestrzennej rozbudowy składowiska odpadów komunalnych Barycz w Krakowie, III etap składowiska, 1997-1998 - PAN CPPGSMiE Kraków, (unpublished work, the Archive of Wieliczka Salt Mine) (in Polish).

Garlicki, A. and Szybist, A. 1995. Ogólne założenia dla zabezpieczenia Kopalni Soli Wieliczka oraz nowy obraz geologiczny złoża wielickiego. Materiały z III Spotkania Polskiego Stowarzyszenia Górnictwa Solnego. Likwidacja zagrożenia wodnego dla zabezpieczenia Kopalni Soli Wieliczka, pages 15-30 (in Polish).

Garlicki, A. and Wilk, Z. 1993. Geologiczne i hydrogeologiczne tło awarii na poziomie IV kopalni soli Wieliczka. Przegląd Geologiczny No 3, pages 183-192 (in Polish).

Garlicki et al. 1996 - Garlicki, A., Pulina, M. and Różkowski, J. 1996. Wpływ zjawisk krasowych na zagrożenie wodne kopalni soli Wieliczka. Przeglad Geologiczny No 10, pages 1032-1038 (in Polish).

James, S.C. 1977. Metals in Municipal Landfill Leachate and Their Health Effect. American Journal of Public Health 67(5), pages 429-432.

Kabata-Pendias, A. and Pendias, H. 1999. Biogeochemia pierwiastków śladowych. Wydawnictwo PWN (in Polish).

Klojzy-Karczmarczyk, B. and Mazurek, J. 2009. Zakres monitoringu wybranych składowisk odpadów; (Range of monitoring of selected waste dumps). Zeszyty Naukowe IGSMiE PAN No 75, pages 13-20.

Klojzy-Karczmarczyk, B. and Mazurek, J. 2010. The grounds for determining additional index parameters in the monitoring process of water environment in the vicinity of municipal waste landfill. [In:] XXXVIII IAH Congress - Groundwater Quality Sustainability; Topic 1.6 - Groundwater monitoring; Wyd. University of Silesia Press 2010; Abstract Book - Vol. 1: pages 216-217; Extended Abstract: pages 719-725 (2-vol. set $+\mathrm{CD})$.

Klojzy-Karczmarczyk et al. 2003 - Klojzy-Karczmarczyk, B., Mazurek, J. and Czajka, K. 2003. Jakość odcieków a wybór charakterystycznych wskaźników zanieczyszczenia wód wokół składowisk odpadów komunalnych; (Leachate quality and characteristic contaminant indexes of water environment near communal wastes disposal). Current Changes in Hydrogeology XI/2, pages 423-426 (in Polish). 
Klojzy-Karczmarczyk et al. 2012 - Klojzy-Karczmarczyk, B., d'Obyrn, K. and Mazurek, J. 2012.Analysis of Long-Term Changes in Water Chemistry of the Malinówka Stream in the Region of Potencial Municipal Landfill Impact on Barycz Salt Deposit Post-Mining Sites. Polish Journal of Environmental Studies, Wyd. HARD Publishing Company, Olsztyn, Poland, Vol. 21 No 5A, pages 180-185.

Koncepcja programowo-przestrzenna...1998 - Koncepcja programowo-przestrzenna rozbudowy składowiska odpadów komunalnych Barycz w Krakowie, III etap składowiska, 1998 - IGSMiE PAN Kraków, (unpublished work, the Archive of Wieliczka Salt Mine) (in Polish).

Lebiocka, M. 2013. Influence of Old Landfill Leachate Co-deigestion with Sewage Sludge on Heavy Metals Concentration in Digester Effluent. Annual Set The Environment Protection - Rocznik Ochrona Środowiska Vol. 15, pages 466-478.

Mazurek, J. 2007. Deformacje powierzchni w otworowej Kopalni Soli „Barycz”w likwidacji. Czy mogą jeszcze powstawać zapadliska. Górnictwo i Geoinżynieria 31, 3/1, pages 409-422 (in Polish).

Mikołajczak, J. 2006. The assessment of environmental risk on the areas degraded by the landfill. Gospodarka Surowcami Mineralnymi-Mineral Resources Management Vol. 22, No 4, p. 67-74, Wyd. IGSMiE PAN.

Monitoring środowiska...2000-2014 - Monitoring środowiska gruntowo-wodnego $w$ rejonie III etapu składowiska Barycz w Krakowie, lata 2000-2014 - IGSMiE PAN Kraków (unpublished work, the Archive of Wieliczka Salt Mine) (in Polish).

d'Obyrn, K. 2010. Likwidacja pustek poeksploatacyjnych w otworowej kopalni soli jako metoda ochrony powierzchni terenu; (Liquidation of post-exploitation goafs in borehole salt mine, as method of terrain surface protection). Przeglą Górniczy No 10, pages 67-72 (in Polish).

Postawa, A. and d'Obyrn, K. 2013. Zmiany warunków zasilania wycieku W VI-32 w Kopalni Soli Wieliczka w świetle wieloletnich badań izotopowych (Changes of recharge conditions of inflow W VI-32 at Wieliczka Salt Minein the light of long-term isotopic investigations). Biuletyn Państwowego Instytutu Geologicznego 456, pages 465-470 (in Polish).

Rosik-Dulewska, Cz. 2011. Podstawy gospodarki odpadami. Wydawnictwo Naukowe PWN, Warszawa (in Polish).

Szymański, K. and Nowak, R. 2012. Transformacje odcieków jako rezultat technicznych zabiegów na składowiskach odpadów komunalnych (Transformations of leachate as a result of technical treatment at municipal waste landfills). Annual Set The Environment Protection - Rocznik Ochrona Środowiska Vol. 14, pages 337-350 (in Polish).

Wardas et al. 2005 - Wardas, M., Budek, L., Kijas, A. and Rembalska, R. 2005. Wpływ powodzi z 1997 roku na rozprzestrzenienie metali ciężkich w środowisku wód potoku Malinówka, w rejonie wysypiska odpadów komunalnych w Baryczy koło Krakowa. Inżynieria Środowiska Vol. 10, No 1 (in Polish).

Winid, B. 2013. Badania specjacji bromu w wodach o zróżnicowanym zasoleniu na podstawie modelowania geochemicznego (The Study of Bromine Speciation in Water of Varying Salinity, Based on Geochemical Modeling). Annual Set The Environment Protection - Rocznik Ochrona Środowiska Vol. 15, pages 2452-2467, (in Polish).

Witkowski, A.J. 2009. Uwagi o monitoringu wód podziemnych dla składowisk odpadów komunalnych; (Remarks on groundwater monitoring for communal landfills). Biuletyn Państwowego Instytutu Geologicznego, Hydrogeologia IX/2, No. 436 - Current Changes in Hydrogeology, pages 535-546 (in Polsih).

Żygadło, M. 2002. Gospodarka odpadami komunalnymi. Skrypt nr 384, Politechnika Świętokrzyska, Kielce (in Polish) 


\title{
ANALIZA WPLYWU ZLIKWIDOWANEJ KOPALNI SOLI I SKLADOWISKA ODPADÓW KOMUNALNYCH NA JAKOŚĆ WÓD MALINÓWKI W REJONIE BYLEGO OBSZARU GÓRNICZEGO BARYCZ
}

\author{
Słowa kluczowe
}

obszar górniczy Barycz, składowisko odpadów komunalnych, eksploatacja otworowa soli, potok Malinówka, jakość wód powierzchniowych

\section{Streszczenie}

Badania monitoringowe jakości środowiska gruntowo-wodnego na terenach byłego obszaru górniczego Barycz Kopalni Soli w Wieliczce a wykorzystywanego obecnie pod składowanie odpadów komunalnych, prowadzone są nieprzerwanie od 2000 roku. Lokalizacja punktów monitoringu oraz zakres badanych parametrów zostały oparte na posiadanych danych archiwalnych, przy uwzględnieniu lokalnej budowy geologicznej, hydrogeologicznej oraz warunków hydrologicznych w rejonie potencjalnego oddziaływania składowiska. Prowadzony przez Kopalnię Soli Wieliczka S.A. oraz IGSMiE PAN monitoring zlewni Malinówki obejmuje swym zakresem zarówno punkt położony na odcinku powyżej składowiska (punkt E), jak i punkt zlokalizowany poniżej składowiska odpadów komunalnych (punkt D) (rys. 1). Przyjęty system opróbowania pozwala na porównanie aktualnego poziomu zanieczyszczenia poniżej składowiska z lokalnym tłem hydrogeochemicznym, za jakie można uznać wyniki pomiarów składu chemicznego wód w rejonie źródliskowym Malinówki. W pracy przedstawiono, uśrednione w kwartałach, wyniki pomiarów jakości wód Malinówki z lat 2012-2014. Stężenia chlorków oraz azotanów i fosforanów w wodach potoku Malinówka, pobieranych w punkcie poniżej składowiska, kształtują się na średnim poziomie kilka razy wyższym niż w rejonach źródliskowych. Zawartość chlorków w wodach przed składowiskiem kształtuje się na uśrednionym poziomie około $50 \mathrm{mg} / \mathrm{dm}^{3}$, natomiast poniżej składowiska wzrasta czterokrotnie. Zawartość azotanów i fosforanów wzrasta natomiast kilkakrotnie przyjmując jednak niskie wartości na poziomie do kilku $\mathrm{mg} / \mathrm{dm}^{3}$. Generalnie nie zauważa się zdecydowanego podwyższenia zawartości metali ciężkich w punkcie poniżej składowiska. Ich wartości zarówno w punkcie E, jak i w punkcie D są niskie, często poniżej granicy oznaczalności. W wodach potoku Malinówka poniżej składowiska (punkt D) obserwowany jest jedynie niewielki wzrost zawartości miedzi, cynku i rtęci oraz w pojedynczych przypadkach także chromu.

W latach 2012-2014, wykonano dodatkowo kilka serii badań jakości solanek ujmowanych w otworach odprężających oraz grupach otworów na obszarze byłego obszaru górniczego Barycz (otwory E-872 i E-945 oraz E-627 a także grupa otworów S1). Znajomość składu chemicznego solanek oraz porównanie $\mathrm{z}$ parametrami charakterystycznymi dla wód powierzchniowych z obszaru związanego z oddziaływaniem składowiska, może ułatwić wyciaganie wniosków, co do udziału analizowanych źródeł w zanieczyszczeniu wód potoku Malinówka. Solanki charakteryzują się bardzo wysoką mineralizacją, związaną głównie z obecnością chlorków. W pobranych solankach pomierzono ponadto wielkości wskaźników, które charakteryzują się podwyższonymi wartościami w wodach powierzchniowych, w punkcie poniżej składowiska (punkt D). Zawartości azotanów i fosforanów w solankach kształtują się na poziomie uzyskanym dla wód powierzchniowych potoku Malinówka. W solankach analizowano także zawartość rtęci i stwierdzono jej obecność na poziomie nieco wyższym niż w ciekach powierzchniowych w granicach od 0,001 do $0,002 \mathrm{mg} / \mathrm{dm}^{3}$. 
Analiza jakości wód Malinówki oraz solanek może stanowić istotny element w procesie rozpoznania źródeł zanieczyszczeń, spowodowanych byłą eksploatacją górniczą oraz eksploatacją składowiska odpadów komunalnych. Przypuszczalne kierunki przepływu wód infiltrujących z powierzchni oraz wód podziemnych wskazują na istnienie strefy potencjalnego mieszania wód opadowych, płytkich wód podziemnych oraz odcieków ze składowiska. Ze względu na warunki geologiczne i hydrogeologiczne obszaru, widoczny przyrost zawartości chlorków w wodach Malinówki, można wiązać zarówno z potencjalnym oddziaływaniem składowiska, jak też z wpływem pozostałości po dokonanej eksploatacji otworowej soli kamiennej (głównie otwory odprężające oraz deformacje górotworu). Natomiast wzrost zawartości azotanów oraz fosforanów może być wynikiem oddziaływania obiektu składowania odpadów lub lokalnych cieków i rowów odwadniających zasilanych zanieczyszczonymi wodami opadowymi i prawdopodobnie ściekami bytowymi z okolicznych gospodarstw. Wzrost zawartości niektórych metali w wodach możne dodatkowo sugerować negatywne oddziaływanie składowiska odpadów komunalnych. Podwyższenie zawartości rtęci w punkcie poniżej składowiska potwierdza istnienie wzajemnych kontaktów hydraulicznych w górotworze z wodami opadowymi infiltrującymi w podłoże. Istniejące wyniki badań pozwalają na potwierdzenie rodzaju ognisk zanieczyszczeń, jednak nie pozwalają na bardziej dokładne określenie ich wpływu na wielkość sumarycznego ładunku zanieczyszczeń w wodach Malinówki poniżej obszaru górniczego kopalni, a tym samym poniżej I etapu składowiska odpadów w Baryczy. Dla osiągnięcia tego celu wskazana jest weryfikacja i rozszerzenie zakresu badań w analizowanym obszarze.

AN ANALYSIS OF THE IMPACT OF A LIQUDATED SALT MINE

AND AN MUNICIPAL LANDFILL ON THE QUALITY OF THE MALINÓWKA STREAM WATER IN THE FORMER BARYCZ MINING AREA

Key words

Barycz mining area, municipal landfill, borehole salt mining, the Malinówka stream, surface water quality

Abstract

Monitoring studies of the quality of the soil and water environment in the former Barycz mining area of the Wieliczka Salt Mine, a section currently used as municipal landfill, have been continuously conducted since 2000. The location of monitoring sites and the range of the monitored parameters were selected based on available historical data, taking into account the local geological and hydrogeological structure as well as hydrological conditions in the area of potential impact of the landfill. The Malinówka catchment monitoring study conducted by Wieliczka Salt Mine and MEERI PAS covers both a point above the landfill (point E) and a point located below the municipal landfill (point D) (Fig. 1). The adopted sampling scheme allows a comparison of the current level of contamination below the landfill with the local hydrogeochemical background, which the results of the measurements of the chemical composition of water in the headwater region of the Malinówka stream may be taken to represent. The paper presents averaged quarterly results of water quality measurements of the Malinówka stream between 2012 and 2014. Chloride, nitrate, and phosphate concentrations in the waters of the Malinówka stream sampled at the site below the landfill were, 
on average, several times higher than in the headwater regions. The chloride content in the water below the landfill was, on average, about $50 \mathrm{mg} / \mathrm{dm}^{3}$, while below the landfill it increased four-fold. Nitrate and phosphate content increased several-fold, but presented low values of up to several $\mathrm{mg} / \mathrm{dm}^{3}$. Generally, there was no significant increase in heavy metal content at the site below the landfill. Their values both at point $\mathrm{E}$ as well as point $\mathrm{D}$ are low, often below the limit of quantification. In the waters of the Malinówka stream below the landfill (point D), only small increases in copper, zinc, and mercury content, and in individual cases chromium, were observed.

Between 2012 and 2014, this analysis included several series of quality studies of brines from pressure relief wells and groups of wells in the former Barycz mining area (E-872, E-945, and E-627 wells, also S1 group of wells). By knowing the chemical composition of brines and by comparing them with the parameters characteristic of the surface water in the area associated with the impact of the landfill, conclusions can be drawn about the share of the analysed sources in the contamination of the waters of the Malinówka stream. Brines tend to display very high mineralisation associated mainly with the presence of chlorides. In the sampled brines, indices characteristically displaying elevated values in surface waters at the site below the landfill (point D) were also measured. Content of nitrates and phosphates in brines are at the level obtained for surface water of the Malinówka stream. The brines were analysed for mercury content; this was found at a level ranging from 0.001 to $0.002 \mathrm{mg} / \mathrm{dm}^{3}$, i.e. slightly higher than in the surface streams.

An analysis of water quality in the Malinówka stream and in brines may be an important element in the process of identification of pollution sources caused by discontinued mining operations and the ongoing operation of the municipal landfill. The presumed directions of groundwater flow and infiltration indicate a potential mixing zone of rainwater, shallow groundwater, and landfill leachate. Due to the geological and hydrogeological conditions of the area, there is a visible increase in the chloride content in the water of the Malinówka stream which may be related both to the potential impact of the landfill as well as to the impact of the presently discontinued borehole mining of rock salt (mainly pressure relief wells and deformation of rock mass). In contrast, an increase in the content of nitrates and phosphates may be the result of the impact of the landfill or local watercourses and drainage ditches fed by contaminated rainwater and possibly domestic waste from the nearby farms. Additionally, an increase in the content of certain metals in waters may suggest a negative impact from the landfill. An increase in the mercury content at the site below the landfill confirms the existence of two-way hydraulic contacts with infiltration waters in the rock mass. The existing research results make it possible to confirm the type of contamination sources; however, the results are inadequate for a more accurate determination of the impact on the size of the cumulative load of contaminants in the Malinówka stream waters below the mining area, i.e. below the Barycz landfill phase I. Verification and extension of research in the analysed area are recommended to achieve this aim. 